\title{
Ticks of four-toed elephant shrews and Southern African hedgehogs
}

\author{
Authors: \\ Ivan G. Horak ${ }^{1,2}$ \\ Shaun Welman ${ }^{3}$ \\ Stacey L. Hallam ${ }^{3}$ \\ Heike Lutermann ${ }^{4}$ \\ Nomakwezi Mzilikazi ${ }^{3}$ \\ Affiliations: \\ ${ }^{1}$ Department of Veterinary \\ Tropical Diseases, \\ University of Pretoria, \\ South Africa \\ ${ }^{2}$ Department of Zoology \\ and Entomology, University \\ of the Free State, South \\ Africa \\ ${ }^{3}$ Department of Zoology, \\ Nelson Mandela \\ Metropolitan University, \\ South Africa \\ ${ }^{4}$ Department of Zoology \\ and Entomology, University \\ of Pretoria, South Africa \\ Correspondence to: \\ Ivan Horak \\ Email: \\ ivan.horak@up.ac.za \\ Postal address: \\ Private bag X04, \\ Onderstepoort 0110, \\ South Africa \\ Dates: \\ Received: 01 Nov. 2010 \\ Accepted: 12 Dec. 2010 \\ Published: 17 Mar. 2011 \\ How to cite this article: \\ Horak, I.G., Welman, S., \\ Hallam, S.L., Lutermann, H. \\ \& Mzilikazi, N., 2011, 'Ticks \\ of four-toed elephant \\ shrews and Southern \\ African hedgehogs', \\ Onderstepoort Journal \\ of Veterinary Research \\ 78(1): Art. \#243, 3 pages. \\ doi:10.4102/ojvr.v78i1.243
}

C 2011. The Authors Licensee: OpenJournals Publishing. This work is licensed under the Creative Commons Attribution License.
Several studies on ticks infesting small mammals, including elephant shrews, have been conducted in South Africa; however, these studies have included only a single four-toed elephant shrew and no hedgehogs. This study thus aimed to identify and quantify the ixodid ticks infesting four-toed elephant shrews and Southern African hedgehogs. Four-toed elephant shrews (Petrodromus tetradactylus) were trapped in dense shrub undergrowth in a nature reserve in north-eastern KwaZulu-Natal. They were separately housed, first in cages and later in glass terraria fitted with wire-mesh bases to allow detached ticks to fall through for collection. Southern African hedgehogs (Atelerix frontalis) were hand caught on a farm in the eastern region of the Northern Cape Province and all visible ticks were collected by means of tweezers while the animals were anaesthetised. The ticks from each animal were preserved separately in $70 \%$ ethanol for later identification and counting. The immature stages of five ixodid tick species were collected from the elephant shrews, of which Rhipicephalus muehlensi was the most common. It has not been recorded previously on any species of elephant shrew. Three ixodid tick species were collected from the hedgehogs. Large numbers of adult Haemaphysalis colesbergensis, which has not been encountered previously on hedgehogs, were collected from these animals. Four-toed elephant shrews are good hosts of the larvae and nymphs of $R$. muehlensi, and Southern African hedgehogs are good hosts of adult $H$. colesbergensis.

\section{Introduction}

Several papers regarding the role of small mammals as hosts of immature ixodid ticks have been published in South Africa during the past two decades (Braack et al. 1996; Horak \& Cohen 2001; Matthee et al. 2007; Petney et al. 2004). Rock elephant shrews (Elephantulus myurus), and to a lesser extent Cape elephant shrews (Elephantulus edwardii), dominate the tick-associated literature for elephant shrews (Fourie, Horak \& Van den Heever 1992; Fourie et al. 2002; Fourie, Horak \& Woodall 2005). This is primarily because they are the preferred hosts of the immature stages of tick species that affect commercially important livestock (Fourie et al. 2005). However, with the exception of a single four-toed elephant shrew (Petrodromus tetradactylus) examined in northeastern Mpumalanga Province (Fourie et al. 2005), no tick collections have been made from these animals or from Southern African hedgehogs (Atelerix frontalis), another small insectivorous species, during the past 20 years.

To date, the immature stages of only two ixodid tick species have been recorded on four-toed elephant shrews in South Africa (Theiler 1962); however, the immature stages of a further nine species have been collected from them in Zambia (MacLeod 1970) and one in Tanzania (Clifford, Walker \& Keirans 1973). Small numbers of several tick species have been collected from Southern African hedgehogs (Theiler 1962; Walker, Keirans \& Horak 2000), but, with the exception of a small number of species, all of these should be considered accidental infestations and simply a reflection of the abundance of the free-living stages of ticks in a particular region.

The opportunity arose to collect ticks from these two small mammal species during a study on the metabolic rate of four-toed elephant shrews in north-eastern KwaZulu-Natal and a similar study on Southern African hedgehogs in the eastern region of the Northern Cape Province, South Africa. Here we report on the ixodid tick species collected from these animals.

\section{Materials and methods}

Several four-toed elephant shrews were caught at Bonamanzi Game Park $\left(28^{\circ} 03^{\prime} 47.17^{\prime \prime}\right.$, $\left.32^{\circ} 18^{\prime} 06.79^{\prime \prime} \mathrm{E}\right)$ in walk-in wire-mesh traps $(60 \mathrm{~cm} \times 25 \mathrm{~cm} \times 25 \mathrm{~cm})$ during April 2009. Trapping occurred in dense shrub undergrowth where the animals' characteristic runways could be identified. The nine captured animals were subsequently housed separately in cages $(56 \mathrm{~cm} \mathrm{x}$ $34 \mathrm{~cm} \times 20 \mathrm{~cm}$ ) each fitted with a tray to collect any detached ticks, and later in glass terraria $(60 \mathrm{~cm} \times 30 \mathrm{~cm} \times 30 \mathrm{~cm}$ ) fitted with wire-mesh bases to allow detached ticks to fall through. Detached ticks were collected on a daily basis and each animal's were preserved separately in $70 \%$ ethanol in internally labelled bottles. The ticks were identified to species level and counted using a stereoscopic microscope. 
The hedgehogs were caught by hand on and around the farm Plaatfontein $\left(31^{\circ} 01.693^{\prime} \mathrm{S}, 2^{\circ} 45.993^{\prime} \mathrm{E}\right)$. All visible ticks were collected with tweezers from the 12 anaesthetised animals (immediately after implantation of body temperature data loggers). The same collection procedures as for ticks on the elephant shrews were then followed.

\section{Ethical considerations}

All procedures adhered to the Code of Animal Experimentation adopted by the Nelson Mandela Metropolitan University. Ezemvelo KZN Wildlife issued a permit for the capture and transport of elephant shrews (permit number 1462/2009) and the Northern Cape Department of Tourism, Environment and Conservation issued a permit for the capture of hedgehogs (permit number FLORA 036/2009).

\section{Results and discussion Four-toed elephant shrews}

A total of 4007 immature ticks, belonging to five species, were collected from the nine animals, which were all infested (Table 1). The majority of these were larvae and nymphs of Rhipicephalus muehlensi, of which a large proportion were engorged. A few engorged nymphs that had escaped immersion in alcohol moulted into adults, thus confirming the species identification. Despite the region in which the study was conducted encompassing part of the geographic distributions of Rhipicephalus appendiculatus and Rhipicephalus maculatus, only a single larva of each of these species was recovered. In view of these findings, as well as for comparative purposes, the results of previous surveys on ticks infesting nyalas (Tragelaphus angasii) and scrub hares (Lepus saxatilis) in north-eastern KwaZulu-Natal (Horak et al. 1995a; Horak, Boomker \& Flamand 1995b) have been summarised in Table 2.

TABLE 1: Species and number of ticks collected from nine four-toed elephant shrews in north-eastern KwaZulu-Natal.

\begin{tabular}{lcccc}
\hline Tick species & \multicolumn{2}{c}{ Number of ticks collected } & \multirow{2}{*}{$\begin{array}{c}\text { Number of } \\
\text { animals infested }\end{array}$} \\
\cline { 2 - 3 } & Larvae & Nymphs & 2 \\
\hline Haemaphysalis elliptica & 18 & 0 & 5 \\
Haemaphysalis silacea & 1 & 11 & 1 \\
Rhipicephalus appendiculatus & 1 & 0 & 1 \\
Rhipicephalus maculatus & 1 & 0 & 9 \\
Rhipicephalus muehlensi & 2904 & $1071^{\text {a }}$ & 2 \\
\hline
\end{tabular}

a, of these, 19 had moulted to adults.
Large numbers of $R$. appendiculatus, R. maculatus and $R$. muehlensi have previously been collected from nyalas, indicating not only that they are good hosts but also that the geographic distributions of the three tick species overlap in the study region (Table 2). Similarly, scrub hares have been found to be infested with fair numbers of the immature stages of these ticks, but the four-toed elephant shrews harboured only a single larva of each of $R$. appendiculatus and $R$. maculatus, and large numbers of larvae and nymphs of $R$. muehlensi.

Walker et al. (2000) have placed R. muehlensi and R. maculatus within the $R$. appendiculatus group of ticks based on the morphology of their immature stages. This group consists of 11 species. The immature stages of each of these 11 species may infest scrub hares, but only those of $R$. appendiculatus have been collected, and then only in very small numbers, from elephant shrews (MacLeod 1970; Theiler 1962). The present collection of a single larva of each of $R$. appendiculatus and $R$. maculatus, in an environment in which these ticks abound, confirms that elephant shrews are not favoured hosts of the immature stages of ticks in this group. The collection of large numbers of $R$. muehlensi larvae and nymphs from fourtoed elephant shrews is thus remarkable. Furthermore, the large numbers of engorged larvae and nymphs which were recovered, together with the fact that some of the nymphs had moulted to adults, imply that four-toed elephant shrews are excellent hosts of the immature stages of $R$. muehlensi. This host preference resembles that of the immature stages of the six species comprising the Rhipicephalus pravus group of ticks, all of which use elephant shrews as hosts (Clifford et al. 1973; Fourie et al. 2005; MacLeod 1970; Theiler 1962; Walker et al. 2000).

Of the 79 nyalas examined in north-eastern KwaZulu-Natal, 16 harboured all stages of development of Haemaphysalis silacea (Horak et al. 1995b). This tick has never been recorded on an elephant shrew. Its presence in this study, albeit in small numbers, on five of the nine animals examined, suggests that four-toed elephant shrews can serve as hosts of the tick's immature stages. Larvae and nymphs of the Haemaphysalis elliptica group of ticks have been collected in small numbers from rock elephant shrews (Fourie et al. 1992), and now also from four-toed elephant shrews. Their preferred hosts are, however, murid rodents (Braack et al. 1996; Fourie et al. 1992; Matthee et al. 2007).

TABLE 2: Host status of four-toed elephant shrews for three sympatric Rhipicephalus species in north-eastern KwaZulu-Natal.

\begin{tabular}{|c|c|c|c|c|c|c|}
\hline \multirow[t]{2}{*}{ Tick and host species } & \multirow[t]{2}{*}{ Number examined } & \multirow[t]{2}{*}{ Number infested } & \multicolumn{4}{|c|}{ Total number of ticks collected } \\
\hline & & & Larvae & Nymphs & Males & Females \\
\hline Rhipicephalus appendiculatus Nyalas & 79 & 76 & 39889 & 7896 & 5144 & 3936 \\
\hline Scrub hares & 34 & 16 & 92 & 281 & 0 & 0 \\
\hline Four-toed elephant shrews ${ }^{a}$ & 9 & 1 & 1 & 0 & 0 & 0 \\
\hline Rhipicephalus maculatus Nyalas & 79 & 73 & 43393 & 6424 & 162 & 192 \\
\hline Scrub hares & 34 & 5 & 0 & 26 & 0 & 0 \\
\hline Four-toed elephant shrews ${ }^{a}$ & 9 & 1 & 1 & 0 & 0 & 0 \\
\hline Rhipicephalus muehlensi Nyalas & 79 & 79 & 322159 & 59655 & 21676 & 14446 \\
\hline Scrub hares & 34 & 29 & 841 & 213 & 0 & 0 \\
\hline Four-toed elephant shrews ${ }^{a}$ & 9 & 9 & 2906 & 1037 & 0 & 0 \\
\hline
\end{tabular}

a, present study. 


\section{Southern African hedgehogs}

A total of 204 ticks belonging to three species were collected from the 12 examined animals, of which 11 were infested (Table 3). The majority of the ticks were adult Haemaphysalis colesbergensis, of which a large proportion of the females were engorged. An old male that harboured 55 male and 43 female $H$. colesbergensis was among the 11 infested animals. $H$. colesbergensis has been described only recently (Apanaskevich \& Horak 2008) and is named after the town Colesberg (in the eastern region of the Northern Cape Province) where adult ticks have been collected from a dog, domestic cats, caracals (Caracal caracal) and an African wildcat (Felis silvestris). Their tick burdens are summarised in Table 4 for comparative purposes.

The numbers now recovered from the hedgehogs and the fact that several females were engorged indicate that these small mammals should also be considered preferred hosts of $H$. colesbergensis. Its presence on Southern African hedgehogs is not entirely unexpected, as hedgehogs seem to be one of the preferred hosts of ticks belonging to this genus. In fact, Haemaphysalis norvali, a species that appears to be specific to hedgehogs, has been described in Zimbabwe (Hoogstraal \& Wassef 1983). To our knowledge $H$. norvali is not present in South Africa.

A larva and five nymphs of the South African tortoise tick, Amblyomma marmoreum, were collected from four of the hedgehogs. The immature stages of $A$. marmoreum infest an extremely wide range of domestic and wild mammals and birds in South Africa (Horak et al. 2006) and hedgehogs are no exception (Theiler 1962). Although none were recovered now, the adults of Rhipicentor nuttalli also infest hedgehogs (Fourie et al. 2002; Norval \& Colborne 1985; Theiler 1962) and several wild carnivores, of which the larger felids appear to be the hosts of choice (Horak, Heyne \& Donkin 2010; Norval \& Colborne 1985). The immature stages of $R$. nuttalli infest elephant shrews, of which the rock elephant shrew and the Cape elephant shrew are the most favoured (Fourie et al. 2002, 2005).

\section{Conclusion}

Four-toed elephant shrews are a new host record for the larvae and nymphs of $R$. muehlensi, a tick of which all stages of development infest nyalas in north-eastern KwaZulu-Natal.

TABLE 3: Species and number of ticks collected from 12 Southern African hedgehogs in the eastern region of the Northern Cape Province.

\begin{tabular}{lccccc}
\hline Tick species & \multicolumn{3}{c}{ Total number of ticks collected } & $\begin{array}{c}\text { Number of } \\
\text { animals infested }\end{array}$ \\
\cline { 2 - 6 } & Larvae & Nymphs & Males & Females & animan \\
\hline Amblyomma marmoreum & 1 & 5 & 0 & 0 & 4 \\
Haemaphysalis colesbergensis & 0 & 1 & 117 & 79 & 11 \\
Haemaphysalis sp. & 0 & 0 & 1 & 0 & 1 \\
\hline
\end{tabular}

TABLE 4: Hosts and number of Haemaphysalis colesbergensis collected from carnivores near Colesberg in the eastern region of the Northern Cape Province.

\begin{tabular}{lccc}
\hline Host species & \multicolumn{2}{c}{ Total number of ticks collected } & $\begin{array}{c}\text { Number of } \\
\text { animals infested }\end{array}$ \\
${$\cline { 2 - 3 }$} }$ & Females & 5 & 1 \\
Domestic dogs & 23 & 131 & 5 \\
Domestic cats & 112 & 2 & 2 \\
Caracals (Caracal caracal) & 7 & 31 & 1 \\
\hline African wildcats (Felis silvestris) & 55 & & \\
\hline
\end{tabular}

Large numbers of adult $H$. colesbergensis may infest Southern African hedgehogs and several species of carnivores in the eastern region of the Northern Cape Province. The hedgehogs constitute a new host record for this tick species.

\section{Acknowledgements}

We thank the staff at Bonamanzi Game Park for their hospitality and assistance. Thanks are also due to Ezemvelo KZN Wildlife and the Northern Cape Department of Tourism, Environment and Conservation for the capture and transport permits. We are most grateful to Mr and Mrs J. Theron, on whose farm the hedgehogs were collected. This study was financed by the National Research Foundation of South Africa, the Oppenheimer Memorial Trust and the Nelson Mandela Metropolitan University.

\section{References}

Apanaskevich, D.A. \& Horak, I.G., 2008, 'Two new species of African Haemaphysalis ticks (Acari: Ixodidae), carnivore parasites of the H. (Rhipistoma) leachi group', Journal of Parasitology 94, 594-607. doi:10.1645/GE-1374.1, doi:10.1645/GE1374R.1, PMid:18605788

Braack, L.E.O., Horak, I.G., Jordaan, L.C., Segerman, J. \& Louw, J.P., 1996, 'The comparative host status of red veld rats (Aethomys chrysophilus) and bushveld gerbils (Tatera leucogaster) for epifaunal arthropods in the southern Kruge National Park, South Africa', Onderstepoort Journal of Veterinary Research 63, 149-158.

Clifford, C.M., Walker, J.B. \& Keirans, J.E., 1973, 'Clarification of the status of Rhipicephalus kochi Dönitz, 1905 (Ixodoidea, Ixodidae)', Onderstepoort Journal of Veterinary Research 50, 77-89.

Fourie, L.J., Horak, I.G. \& Van den Heever, J.J., 1992, 'The relative host status of rock elephant shrews Elephantulus myurus and Namaqua rock mice Aethomys namaquensis for economically important ticks', South African Journal of Zoology 27, 108-114.

Fourie, L.J., Horak, I.G., Kok, D.J. \& Van Zyl, W., 2002, 'Hosts, seasonal occurrence and life cycle of Rhipicentor nuttalli (Acari: Ixodidae)', Onderstepoort Journal of Veterinary Research 69, 177-187.

Fourie, L.J., Horak, I.G. \& Woodall, P.F., 2005, 'Elephant shrews as hosts of immature ixodid ticks', Onderstepoort Journal of Veterinary Research 72, 293-301.

Hoogstraal, H. \& Wassef, H.Y., 1983, 'Notes on African Haemaphysalis ticks. XV. H. (Rhipistoma) norvali sp. n., a hedgehog parasite of the $H$. (R.) spinulosa group in Zimbabwe (Acarina: Ixodidae)', Onderstepoort Journal of Veterinary Research 50, 183-189.

Horak, I.G., Spickett, A.M., Braack, L.E.O., Penzhorn, B.L., Bagnall, R.J. \& Uys, A.C., 1995a, 'Parasites of domestic and wild animals in South Africa. XXXIII. Ixodid ticks on scrub hares in the north-eastern regions of Northern and Eastern Transvaal and of KwaZulu-Natal', Onderstepoort Journal of Veterinary Research 62, 123-131.

Horak, I.G., Boomker, J. \& Flamand, J.R.B., 1995b, 'Parasites of domestic and wild animals in South Africa. XXXIV. Arthropod parasites of nyalas in north-eastern KwaZulu-Natal', Onderstepoort Journal of Veterinary Research 62, 171-179.

Horak, I.G. \& Cohen, M., 2001, 'Hosts of the immature stages of the rhinoceros tick, Dermacentor rhinocerinus (Acari, Ixodidae)', Onderstepoort Journal of Veterinary Research 68, 75-77.

Horak, I.G., Mckay, I.J., Heyne, H. \& Spickett, A.M., 2006, 'Hosts, seasonality and geographic distribution of the South African tortoise tick, Amblyomma marmoreum', Onderstepoort Journal of Veterinary Research 73, 13-25.

Horak I.G., Heyne, H. \& Donkin, E.F., 2010, 'Parasites of domestic and wild animals in South Africa. XLVIIII. Ticks (Acari: Ixodoidea) infesting domestic cats and wild felids', Onderstepoort Journal of Veterinary Research 77(1): Art. \#3, 7 pages. doi:10.4102/ojvr.v77i1.3.

MacLeod, J., 1970, 'Tick infestation patterns in the southern province of Zambia', Bulletin of Entomological Research 60, 253-274. doi:10.1017/S0007485300040773

Matthee, S., Horak, I.G., Beacournu, J.C., Durden, L.A., Ueckermann, E.A. \& McGeoch, M.A., 2007, 'Epifaunistic arthropod parasites of the four-striped mouse, Rhabdomys pumilio, in the Western Cape Province, South Africa', Journal of Parasitology 93, 47-59. doi:10.1645/GE-819R2.1, PMid:17436941

Norval, R.A.I. \& Colborne, J., 1985, 'The ticks of Zimbabwe. X. The genera Dermacentor and Rhipicentor', Zimbabwe Veterinary Journal 16, 1-4.

Petney, T.N., Horak, I.G., Howell, D.J. \& Meyer, S., 2004, 'Striped mice, Rhabdomys pumilio, and other murid rodents as hosts for immature ixodid ticks', Onderstepoort Journal of Veterinary Research 71, 313-318.

Theiler, G., 1962, The Ixodoidea parasites of vertebrates in Africa south of the Sahara (Ethiopian region), Division of Veterinary Services, Onderstepoort, (mimeographed).

Walker, J.B., Keirans, J.E. \& Horak, I.G., 2000, The genus Rhipicephalus (Acari, Ixodidae): a guide to the brown ticks of the world, Cambridge University Press, Cambridge. 